Starenki Dmytro 論文内容の論旨

主 論 文

\title{
Induction of thyroid cancer cell apoptosis by a novel nuclear factor $K B$ inhibitor, dehydroxymethylepoxyquinomicin
}

\author{
Nuclear Factor k B 新規阻害剂、デヒドロキシメチルエポキシキノマイシンを用いた \\ 甲状腺癌細胞に対するアポトーシス誘導治療) \\ Dmitriy V. Starenki、難波 裕幸、ウラジミール・サエンコ、 \\ 大津留 晶、前田 茂人、梅澤 一夫、山下 俊一
}

Clinical Cancer Research Oct 15; 10(20):6821-9, 2004

長崎大学大学院医学研究科 生理系専攻 指導教授 :山下 俊一 教授)

\section{緒 言】}

甲状腺末分化癌は極めて悪性度が高く、放射線治療や抗がん斉に対してもアポトーシス抵抗性で、急速 な進行と高い致死率を示す。Nuclear factor-kappaB NF- k B)は、細胞の増殖とアポトーシス調節に関わ る重要な細胞内情報伝達因子であり NF- K B の活性化により 抗アポトーシス関連遺伝子群である TRAF、IAPs、p21や Bcl-XL などの発現が光進し、細胞死に対して防御的に働くとか知られている。既 に我々は、甲状腺未分化癌及び甲状腺分化癌の一部ではNF- $\mathrm{K} B$ の活性が高く、光れか悪性度や治療 抵抗性の一因であることを、明らかにしている \$tarenki D., et. al. J Clin Endocrinol Metab 89:410-18, 2004)。一方、毒性のない抗生物質 epoxyquinomicin の構造をもとに、近年 NF- k B を阻害するシグナル 伝達阻害剂として、Dehydroxymethylepoxyquinomicin DHMEQ)が分子デザインされ、新たに合成可能 となった。光こで本研究では、甲状腺末分化癌を含む各種甲状腺癌細胞株に対して、DHMEQ の効果を、 正常甲状腺初代培養細胞と比較し、in vitro、in vivoで検討し、さらに炎の分子薬理機構を明らかにした。

\section{对象と方法】}

1) 細胞：甲状腺末分化癌細胞株 FRO、ARO、KTC- 2、乳頭癌細胞株 TPC- 1、KTC- 1、及び濾胞癌 細胞株 WRO を用い、対照として甲状腺初代培養細胞を用いた。

2) ウエスタン・ブロッテイング：細胞抽出液のSDS PAGE 電気泳動を行い、ニトロルロース膜に転写 後、各種アポトーシス関連因子抗体を用いて免疫ブロッティングを行った。 
3) NF- K B DNA- binding assay：NF- K B 結合部位を含むオリゴヌクレオチトで被覆したプレートと核抽 出物を反応させ、結合したNF- $\mathrm{k} B$ を抗原抗体反応で検出し、吸光度分析を行った。

4) Cell survival assay : DHMEQ とMAPK ファミリーの阻害剂を含む溶液を種々の濃度で加え、 water- soluble tetrazolium salt based assay WST )を行い、吸光度分析を行った。

5) フローサイトメトル解析 : annexin V とpropidium iodide(PI)とて採取した細胞に二重染色を行い、フ ローサイトメトーによるアポトーシスと細胞壊死の解析を行った。

6) ヌードウスへの腫瘍細胞移植モデル：BALB/c nu/nu マウスの側腹部に FRO 細胞を皮下注射し た。DHMEQ 投与群 $8 \mathrm{mg} / \mathrm{kg} /$ 日、腫瘍移植 5 日目より2週間、腹腔内投与) とコントロール群、各 8 匹のマウスを用い 5 日おきに腫瘍体積を測定した。また腫瘍組織切片中のアポトシス細胞を A popT ag Peroxidase Kit を用いて検出した。

\section{結 果】}

1) DHMEQ は甲状腺癌細胞に対して、低濃度 $10 \mu \mathrm{g} / \mathrm{m}$ 以下)で、細胞死効果を示した。一方、正常 甲状腺細胞では低濃度では細胞生存には影響なかった。

2) 甲状腺癌細胞に対し、DHMEQ 投与群では、NF- $\mathrm{k}$ B の p65 とp50サブユニッけ核へのトランスロ ケーシシン、及び RelA/p65のDNA への結合を著明に抑制した。

3) DHMEQ はIAP ファミリータンパク質であるCIAP- 1、 CIAP- 2 及びXIAP の表出を抑制した。

4) DHMEQ は 0.1〜 $5 \mu \mathrm{g} / \mathrm{ml}$ の範囲では、カスパーゼ依存性のアポトーシスを誘導した。これは JNK 阻 害剂では抑制されたが、MEK 及び p38阻害剂では抑制されなかった。

5) 正常ヒ怞来甲状腺細胞は、DHMEQ Q.1〜 $5 \mu \mathrm{g} / \mathrm{ml})$ のアポトーシス誘導効果や各種カスパーゼの 発現増加は認めなかつた。

6) ヌードマウスでは、DHMEQ は明らかな副作用なしに腫瘍の増大を著明に抑制し、組織学的にもアポ トーシス細胞の増加を認めた。

\section{䓔察】}

DHMEQ は低濃度処理でin vitro、in vivo 両実験系において、甲状腺癌細胞に対しアポトーシスによる細 胞死を誘導した。光の機序は選択的 NF- K B 活性抑制に加え、JNK 活性化が考えられた。また、正常甲 状腺細胞は DHMEQ によるアポトーシス誘導効果は認めず、癌細胞選択的にアポトーシスを誘導できる と考えられた。これまでサリトママイ゙をはじめ既存のNF- $\mathrm{k}$ B 活性抑制作用を有する薬剂による治療効果 か樣々検討されてきたが、ごく部の癌腫を除き产の効果は明らかでなかった。甲状腺癌でも、放射線や 抗癌剂との併用て限定的に効果が見られることを我々は確認している。他の癌でも同樣に併用療法での 効果は報告されているが、臨床応用できるものは極めて限られている。本研究により 新規 NF- $\mathrm{K} B$ 阻害 剂 DHMEQ を用いた甲状腺癌治療の有効性と、光の癌細胞選択的細胞死劝ズムか明らかとなた。 これまで有効な゙治療法のなかった進行甲状腺癌に対し、今後 DHMEQ による臨床治験に向けた可能性 か期待される。 